\title{
The effect of powdered juice on human dental enamel dissolution
}

\author{
- Stella da Silva Ferreira Department of Dentistry, School of Dentistry, University of São Paulo, São Paulo, SP, Brazil • \\ Débora Perroni da Cruz Department of Dentistry, School of Dentistry, University of São Paulo, São Paulo, SP, Brazil • Michel \\ Nicolau Youssef Department of Dentistry, Cruzeiro do Sul University, São Paulo, SP, Brazil • Idalina Vieira Aoki Department \\ of Chemical Engineering, Polytechnic School, University of São Paulo, São Paulo, Brazil • Rocio del Pilar Benzedu \\ Hernandez Department of Chemical Engineering, Polytechnic School, University of São Paulo, São Paulo, Brazil • Maria \\ Angela Pita Sobral Department of Dentistry, School of Dentistry, University of São Paulo, São Paulo, SP, Brazil
}

ABSTRACT | Aim: The aim of this in vitro study was to evaluate the dissolution potential of an artificial powdered juice in human dental enamel. Methods: Three commercially available beverages were tested by first evaluating the $\mathrm{pH}$ and the titratable acidity. After this, 40 enamel specimens were individually immersed for $120 \mathrm{~min}$ in the respective solutions $(\mathrm{n}=$ 8): C-: distilled water (negative control); TAN: powdered orange juice; DEL: natural orange juice; CC: Coca-Cola ${ }^{\circledR}$ and $\mathrm{C}+: 1 \%$ citric acid solution (positive control). At the end, each solution was analyzed for the amount of calcium (Ca) released and the data obtained were analyzed using ANOVA followed by Tukey's test ( $\mathrm{p}<0.05)$. Results: All solutions had low $\mathrm{pH}$ values. Group C+ had the highest titratable acidity, followed by DEL, TAN and CC. TAN (0.92 \pm 2.0$)^{\mathrm{a}}$ resulted in a lower release of $\mathrm{Ca}$, being statistically similar to group C- $(0.46 \pm 0.8)^{\mathrm{a}}$, while $\mathrm{CC}(6.32 \pm 1.4)^{\mathrm{c}}$ resulted in the higher release of calcium, followed by groups C+ $(4.17 \pm 1.0)^{\mathrm{bc}}$ and DEL $(3.13 \pm 2.0)^{\mathrm{b}}$ groups. Relevance: The artificial powdered juice tested, although its $\mathrm{pH}$ is low and its titratable acidity is high, caused no enamel dissolution.

DESCRIPTORS | Dental Enamel; Hydrogen-Ion Concentration; Beverages; Citric Acid.

RESUMO | 0 efeito do suco artificial em pó na dissolução do esmalte dental humano • Objetivo: O objetivo deste estudo in vitro foi avaliar o potencial de dissolução do suco artificial em pó sobre o esmalte dental humano. Métodos: Três bebidas disponíveis comercialmente foram testadas, avaliando-se primeiramente o pH e a acidez titulável. Em seguida, 40 espécimes de esmalte foram imersos individualmente durante $120 \mathrm{~min}$, nas respectivas soluções ( $\mathrm{n}=8$ ): C-: água destilada (controle negativo); TAN: suco artificial em pó sabor laranja; DEL: suco de laranja natural; CC: refrigerante Coca-Cola ${ }^{\circledR}$ e C+: solução de ácido cítrico $1 \%$ (controle positivo). Ao final, cada solução foi analisada em relação à quantidade de cálcio (Ca) liberado e os dados obtidos foram analisados através da ANOVA, seguido pelo teste de Tukey $(\mathrm{p}<0,05)$. Resultados: Todas as soluções apresentaram baixos valores de $\mathrm{pH}$. O grupo C+ apresentou a maior acidez titulável, seguido pelos grupos DEL, TAN e CC. O grupo TAN resultou na menor liberação de Ca $(0,92 \pm 2,0)^{\mathrm{a}}$, sendo estatisticamente semelhante ao grupo C- $(0,46 \pm 0,8)^{\mathrm{a}}$, enquanto o grupo CC $(6,32 \pm 1,4)^{\mathrm{c}}$ resultou na maior liberação de cálcio, seguido pelos grupos $\mathrm{C}+(4,17 \pm 1,0)^{\mathrm{bc}} \mathrm{e}$

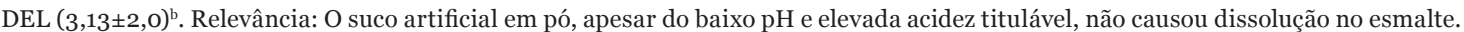

DESCRITORES | Esmalte Dentário; pH; Bebidas; Ácido Cítrico.

CORRESPONDING AUTHOR: | - Maria Angela Pita Sobral Department of Dentistry, School of Dentistry, University of São Paulo Av. Prof. Lineu Prestes, 2227 • 05508-900 São Paulo, SP, Brazil E-mail: mapsobra@usp.br

- Received Apr 27, 2015 • Accepted Sep 5, 2015

- Dol http://dx.doi.org/10.11606/issn.2357-8041.clrd.2015.97559 


\section{INTRODUCTION}

Over the last few decades, a notable decline in the prevalence of dental caries in the population has been observed. However, other previously existing dental problems began to receive more attention. ${ }^{1}$ In this context, the loss of dental hard tissue unrelated to the presence of bacteria, denominated non-carious lesions (NCL), has been clinically more frequent, especially dental erosion.

Dental erosion is defined as irreversible dental hard tissue loss due to a chemical process that does not involve bacteria ${ }^{2}$, mainly caused by the action of extrinsic factors. Among these, the excessive consumption of acid beverages ${ }^{3}$ has frequently been related to greater prevalence of this type of lesion. The change in habits and people's lifestyle has influenced the increase in the consumption of fruit juices, due to the adoption of healthier dietary habits. Simultaneously, people have increasingly sought food and drinks of more practical preparation, as powdered fruit juices.

A research conducted by the Brazilian Association of Soft Drink and Non-Alcoholic Beverage Industries ${ }^{4}$ (Associação das Indústrias de Refrigerantes e de Bebidas Não Alcóolicas ABIR), between the years 2002 and 2009 showed that there has been an increasing juice consumption in Brazil over last years, with emphasis on the categories of natural juices, nectars and powdered artificial "juices". Their consumption increased by $33 \%$ in the last seven years and the orange flavor was appointed as the top seller. The explanation for this may be related to the easy acquisition, low cost, variety of flavors and practicality of preparing this type of beverage. Furthermore, the composition of these beverages has been modified over the years, with vitamins and other components added, which made it more attractive to the consumer.

In the literature, there are few reports that have evaluated the potential of this type of beverage to cause tooth enamel dissolution. The studies of Corso et al. ${ }^{5}$ and Gonçalves et al. ${ }^{6}$ evaluated the erosive potential of some artificial powdered juices and showed that these beverages present low $\mathrm{pH}$ values and are considered potentially acidic. It is known that the medium becomes subsaturated in relation to enamel and dentin after the ingestion of acidic foods, which promotes the release of hydrogen ions and the dissolution of calcium and phosphate minerals. ${ }^{7}$ Although $\mathrm{pH}$ alone is the better indicator of the erosive potential of a beverage, ${ }^{8}$ there are other important chemical factors that may be of significant influence.7,8 The titratable acidity expresses the buffer capacity of a beverage, which is defined as the ability to resist the $\mathrm{pH}$ changes when an acid or a base is added, ${ }^{9}$ so the higher the buffer capacity of a beverage, the longer it will take for saliva to neutralize its acidity. ${ }^{10}$ Both parameters cited above have been described as relevant factors of erosion. ${ }^{11-13}$ The calcium content release ${ }^{8}$ was also described as good predictor of erosion. Thus, these three factors allow a more complete analysis of the erosive potential of a beverage, ${ }^{14}$ and should therefore be evaluated.

Bearing in mind the foregoing, the aim of this in vitro study was to evaluate the dissolution potential of an artificial powdered fruit juice, natural orange juice and a soft drink in human dental enamel, through $\mathrm{pH}$ analysis, titratable acidity and the quantification of calcium ions released.

\section{MATERIALS AND METHODS}

\section{Experimental Design}

In this in vitro study, an artificial powdered orange juice, natural orange juice and a soft drink were tested in two independent stages. A 1\% citric acid solution and distilled water were used as positive and negative controls, respectively. In the first phase, the $\mathrm{pH}$ and titratable acidity values of the selected beverages and of the positive control were characterized. In the second phase, the dissolution potential of the beverages and controls (positive 
and negative) was tested using an in vitro erosion model. The response variable was the alteration in the amount of calcium present in the solutions (in ppm), measured by a calcium-selective electrode.

\section{Phase 1}

\section{Beverages Selection}

Tang ${ }^{\circledR}$ powdered orange juice (TAN) (Kraft Foods Brasil S.A.) was selected for this study and compared with natural orange juice - Del Valle ${ }^{\circledR}$ (DEL) (The Coca-Cola Company, Atlanta, GA, USA) - and a soft drink - Coca-Cola ${ }^{\circledR}$ (CC) (The CocaCola Company, Atlanta, GA, USA). A citric acid solution (1\%) was used as positive control (C+), and distilled water as negative control (C-).

\section{Determination of $\mathrm{pH}$ and Titratable Acidity (TA)}

TAN was prepared immediately before the analyses, in accordance with the "method of preparation" recommended by the manufacturer. $\mathrm{CC}$ was opened and agitated in a magnetic agitator for 60 min before use, to remove all the carbonation, ${ }^{15}$ and DEL was used right after opening the pack. For the analyses, all the beverages were used at room temperature.

Determination of $\mathrm{pH}$ was performed in triplicate, with $60 \mathrm{~mL}$ samples of each solution, using a calibrated $\mathrm{pH}$ electrode (Accumet 13-620-530; Fisher Scientific, Pittsburgh, PA, USA). For titratable acidity analysis, measurement was also performed in triplicate. In this case, aliquots of $1 \mathrm{M}$ $\mathrm{NaOH}$ were added to $60 \mathrm{~mL}$ samples of each solution, and the total volume (in $\mathrm{mL}$ ) of base necessary to raise the initial $\mathrm{pH}$ of the solutions to 7.0 was recorded.

\section{Phase 2}

\section{Specimens Preparation}

The study was conducted after approval by the local Ethics Committee (registration number 123/2010). Twenty healthy unerupted human third molars were used to obtain 40 enamel specimens. Initially, the crowns were separated from the roots using an automatic cutter (Isomet Buehler). After this, the coronal portion was vertically sectioned in the mesio-distal direction, to obtain two enamel fragments $(4 \times 4 \times 2 \mathrm{~mm})$. Each fragment was embedded in an acrylic resin block, and these blocks were then flattened with abrasive $\mathrm{Al}_{2} \mathrm{O}_{3}$ discs (400-, 600-, 1200- and 4000-, Buehler) under cooling, and polished with a felt disc and diamond paste to produce a flat, smooth surface. The 40 enamel specimens obtained were randomly distributed among the 5 experimental groups $(n=8)$.

\section{Erosive Challenge}

Before the erosive challenge, the specimens' surfaces received the application of an adhesive tape (Graphic tape, Chartpak, Leeds, MA, USA) on the margins, maintaining a central test window $(4 \times 2 \mathrm{~mm})$. After this, the specimens were submitted to an in vitro model of erosive challenge. Initially, one sample of each solution, not yet submitted to immersion of the specimen, was used as "standard" for determination of the initial amount of calcium present. Next, the specimens were immersed in the respective solutions for $120 \mathrm{~min}$ and at the end, the solutions were stored at $4^{\circ} \mathrm{C}$ for 24 hours, until the calcium analysis was performed.

\section{Calcium Analysis}

For each experimental group, 9 solutions (1 "standard" + 8 experimental solutions) were analyzed. Quantification of the calcium released after immersion was performed in duplicate, with the solutions at room temperature using a calciumion selective electrode (Mettler-Toledo Ind. e Com. Ltda, Barueri, São Paulo, Brazil). The mean of the final calcium values (expressed in ppm) obtained for each solution was calculated, and then the difference between the amount of calcium released in the solution and the initial amount of calcium 
in the "standard" solution was calculated, for later comparison among the groups.

\section{Statistical Analysis}

Data were analyzed by one-way ANOVA, followed by Tukey's test, with a significance level of $5 \%$. For data analysis, the software BioEstat version 5.0 was used.

\section{RESULTS}

\section{Phase 1}

The means of the $\mathrm{pH}$ and titration values obtained for the experimental groups are shown in Table 1. Group $\mathrm{C}+$ presented the lowest $\mathrm{pH}$ value in comparison with the other experimental groups. Among the beverages analyzed, CC presented the lowest initial $\mathrm{pH}$ value, followed by TAN and DEL.

As regards titratable acidity, $\mathrm{CC}$ required the smallest volume of base to raise the $\mathrm{pH}$ and achieve neutrality, when compared with the other experimental groups. TAN and DEL presented similar titration values, much higher than that of $\mathrm{CC}$, while group $\mathrm{C}+$ required the largest volume of base to achieve $\mathrm{pH}$ 7.0. group $\mathrm{C}$ - presented a neutral $\mathrm{pH}$ value and for this reason the titratable acidity analysis was not performed in this group.

Table 1 | Means of the $\mathrm{pH}$ and titratable acidity values obtained for the experimental groups.

\begin{tabular}{c|c|c}
\hline Group & $\mathrm{pH}$ & Titratable Acidity $(\mathrm{pH} \mathrm{7.0})^{*}$ \\
\hline C- & 7.0 & -- \\
\hline TAN & 2.97 & 3.5 \\
\hline DEL & 3.34 & 3.9 \\
\hline CC & 2.57 & 1.9 \\
\hline C+ & 2.34 & 7.4 \\
\hline
\end{tabular}

${ }^{*}$ Titratable acidity is represented by the volume $(\mathrm{mL})$ of $1 \mathrm{M} \mathrm{NaOH}$ needed to reach $\mathrm{pH}$ 7.0.

Figure 1 presents the titration curve obtained for the three beverages tested and for the positive control group. It may be observed that group $\mathrm{C}+$ presented the largest titration curve, in very slow ascension. The curves represented by DEL and TAN are rather similar and the $\mathrm{pH}$ appears to rise proportionally to the additions of the base aliquots. For CC, a curve with abrupt elevation was observed, in which the initial $\mathrm{pH}$ value was raised to over 5 with the addition of only $0.5 \mathrm{ml}$ of $\mathrm{NaOH}$.

\section{Titratable Acidity}

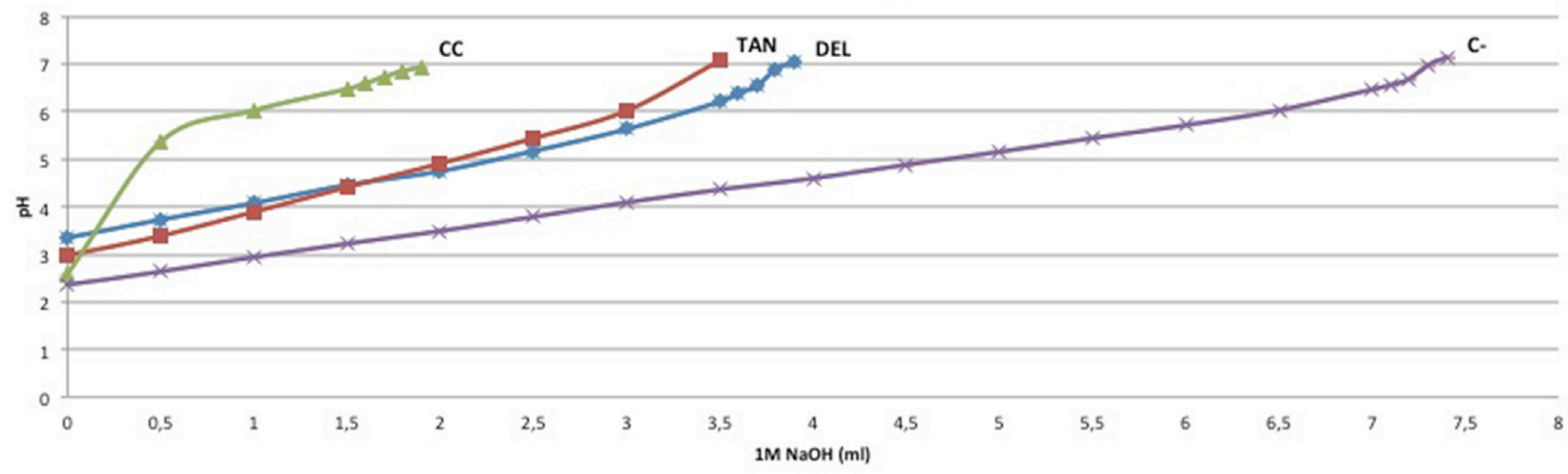

Figure 1 | Titration curve obtained for the three beverages tested and the positive control group.

\section{Phase 2}

The mean values of the initial amount of calcium (Ca) and the mean values \pm SD of the difference between the final and initial amount of calcium $(\Delta \mathrm{Ca})$ are shown in Table 2. TAN and DEL presented a large amount of initial calcium, while $\mathrm{CC}$ contained a small amount of this ion. Group $\mathrm{C}+$, in turn, presented the lowest amount of initial calcium in its 
composition. Regarding the enamel dissolution, it may be observed that groups $\mathrm{C}$ - and TAN caused the lowest release of calcium, being statistically similar to each other and differing from the other experimental groups $(\mathrm{p}<0.05)$. DEL presented intermediate values of calcium released, followed by groups $\mathrm{C}+$ and $\mathrm{CC}$, and the latter resulted in the highest release of calcium from the enamel. These groups were shown to be statistically similar to one another.

Table 2 | Mean values of the initial amount of calcium (Ca) and the mean values $\pm \mathrm{SD}$ of the difference between the final and initial amount of calcium $(\Delta \mathrm{Ca})$ for the experimental groups.

\begin{tabular}{c|c|c} 
Group & Initial $\mathrm{Ca}^{*}$ & $\Delta \mathrm{Ca}^{*}$ \\
\hline C- & 3.31 & $0.46 \pm 0.8^{\mathrm{a}}$ \\
\hline TAN & 36.36 & $0.92 \pm 2.0^{\mathrm{a}}$ \\
\hline DEL & 38.79 & $3.13 \pm 2.0^{\mathrm{b}}$ \\
\hline CC & 8.43 & $6.32 \pm 1.4^{\mathrm{c}}$ \\
\hline C+ & 0.53 & $4.17 \pm 1.0^{\mathrm{bc}}$ \\
\hline
\end{tabular}

* In ppm.

Different superscript letters indicate statistical differences $(p \leq 0.05)$ between lines.

\section{DISCUSSION}

The erosive potential of a beverage is not only dependent on its $\mathrm{pH}$ value, but is also influenced by other chemical factors, such as titratable acidity and the amount of calcium, phosphate and fluoride present in the composition of the beverage. ${ }^{16}$

The $\mathrm{pH}$ is of great importance for determining the erosive potential of a drink, since the solubility of hydroxyapatite, for both enamel and dentin, increases as the $\mathrm{pH}$ decreases, ${ }^{17}$ however, it indicates only the initial acidity of a solution. Since prior to neutralization by saliva, the time that the acid remains active in the oral cavity influences the severity of dental loss, the titratable acidity of a beverage is also an important guide in determining its erosive potential. ${ }^{14}$ Another important factor is related to the amount of calcium present in the beverage composition, where at this rate, acidic beverages are generally undersaturated in relation to hydroxyapatite, which leads to enamel dissolution through the demineralization process. ${ }^{18}$ Therefore, in order to perform a more comprehensive evaluation of the erosive potential of a beverage, it is important that these three factors can be jointly determined. ${ }^{14}$ In this study, the evaluation of $\mathrm{pH}$ showed that the three beverages tested presented $\mathrm{pH}$ values below 3.34, characterizing them with the potential to erode enamel. If only the $\mathrm{pH}$ of a beverage is taken into consideration, it may be suggested that Coca-Cola, among the tested beverages, would be the one with the highest potential to cause enamel dissolution, as previously described by Furtado et al. ${ }^{14}$

However, by the titration curve obtained, it may be observed that Coca-Cola ${ }^{\circledR}$ presented low titratable acidity, while Tang ${ }^{\circledR}$ and Del Valle ${ }^{\circledR}$ juices presented a different behavior, requiring a volume of base almost two times larger for their neutralization than that needed for Coca-Cola ${ }^{\circledR}$. This finding corroborates with previous studies reported in the literature. ${ }^{12-14,19}$

The simple citric acid solution, in turn, used as positive control, presented the highest acidity and required a much larger volume of base to neutralize its $\mathrm{pH}$ when compared with the other solutions tested. This fact had been expected, due to the harmful effect that citric acid has on the tooth surface, explained by its double action arising from both the direct attack of the hydrogen ions on the surface of the crystal and the chelating action of the citrate ions in the calcium complexation from the tooth structure. ${ }^{7}$

On the other hand, when evaluating the amount of calcium released, it was evident that the powered orange juice Tang, in spite of presenting a high titratable acidity, contains a large amount of calcium in its composition, which makes it supersaturated in relation to enamel mineral. Thus, it showed the lowest level of Ca ion release from enamel, and does not 
present the potential to cause dissolution of this substrate. This fact is interesting and draws attention to the reformulation that has occurred in the composition of this type of beverage, since the addition of calcium has brought about great benefits, such as the lower dissolution potential, compared with the soft drink and natural orange juice tested.

Del Valle orange juice, although also presenting a significant amount of calcium ions in its composition, behaved in a different manner than Tang juice. The results for Del Valle juice with respect to Ca ion release from enamel were similar to those of Coca-Cola $^{\circledR}$, which resulted in a higher level of calcium released among the beverages tested in this study.

Evaluating the analyses of $\mathrm{pH}$, titratable acidity and amount of calcium released in the solution, it may be observed that there is no correlation between the results found. It is therefore clear that only the $\mathrm{pH}$ and buffer capacity of a beverage do not determine its dissolution potential, since not every beverage considered acid and presenting an elevated titratable acidity would have the potential to cause enamel dissolution.

In this case, it is important to observe that the beverages tested are composed of different types of acids. In addition to ascorbic acid (Vitamin C), orange juice contains citric acid, naturally present in its composition. ${ }^{20}$ Coca-Cola, on the other hand, contains citric acid and phosphoric acid, and being a carbonated beverage, also contains carbon dioxide $\left(\mathrm{CO}_{2}\right)$ pressurized in the water, which produces carbonic acid $\left(\mathrm{H}_{2} \mathrm{CO}_{3}\right)$, diminishing the $\mathrm{pH}$ of this beverage even further. ${ }^{9}$ Therefore, it is assumed that the different types of acids and their associations, and the difference in their concentration, in addition to the presence of other components, such as calcium ions, may explain the differences in behavior observed for each of the beverages tested in this study. Nevertheless, it is difficult to make this statement, because the manufacturers do not describe all the components and the real amount of each one of them present in the beverages.

According to the method used, the three beverages tested showed low $\mathrm{pH}$ values and a considerable titratable acidity. However, in spite of this and evaluating the release of calcium, the powered juice was not able to cause enamel dissolution. Natural juice showed an intermediate potential to cause enamel erosion, while the soft drink tested was responsible for the higher enamel dissolution.

\section{REFERENCES}

1. Senna A, Del Bel Cury A, Rosing C. Non-carious cervical lesions and occlusion: a systematic review of clinical studies. J Oral Rehab. 2012 Jun;39(6):450-62. doi: 10.1111/j.13652842.2012.02290.x.

2. ten Cate JM, Imfeld T. Dental erosion, summary. Eur J Oral Sci. 1996 Apr;104(2 (Pt 2)):241-4. doi: 10.1111/j.16oo0722.1996.tbooo73.x

3. Dugmore CR, Rock WP. A multifactorial analysis of factors associated with dental erosion. Br Dent J. 2004 Mar;196(5):283-6. doi:10.1038/sj.bdj.4811041.

4. Sebrae. Consumo de suco cresce no Brasil. Associação Brasileira das Indústrias de Refrigerantes e Bebidas Não Alcóolicas [Internet]. 2013 [cited 2013 Dec 17]. Available from: http://gestaoportal.sebrae.com.br/uf/paraiba/produtos-eservicos/setores-atendidos/fruticultura/consumo-de-sucocresce-no-brasil/BIA_18283.

5. Corso S, Padilha DMP, Corso AC, Hugo FN. Avaliação do potencial erosivo de sucos de fruta artificiais em pó, refrigerantes, isotônicos e chás enlatados disponíveis comercialmente no Brasil. RFO UPF. 2006 Jan/Jun;11(1):45-50. doi: 10.5335/rfo.v11i1.1444.

6. Gonçalves GK, Guglielmi CA, Corrêa FN, Raggio DP, Corrêa MS. Erosive potential of different types of grape juices. Braz Oral Res. 2012 Sep-Oct;26(5):457-63. doi: 10.1590/S180683242012005000015 .

7. Featherstone JDB, Lussi A. Understanding the chemistry of dental erosion. Monogr Oral Sci. 2006;20:66-76. doi:10.1159/000093351.

8. Hara AT, Zero DT. Analysis of the erosive potential of calcium-containing acidic beverages. Eur J Oral Sci. 2008 Feb;116(1):60-5. doi: 10.1111/j.1600-0722.2007.00513.x. 
9. Cochrane NJ, Cai F, Yuan Y, Reynolds EC. Erosive potential of beverages sold in Australian schools. Austr Dent J. 2009 Sep;54(3):238-44. doi: 10.1111/j.1834-7819.2009.01126.x.

10. Lussi A, Jaeggi T, Zero D. The role of diet in the aetiology of dental erosion. Caries Res. 2004;38(Suppl 1):34-44. doi: 10.1159/000074360.

11. Lussi A, Jaggi T, Scharer S. The influence of different factors on in vitro enamel erosion. Caries Res. 1993;27(5):387-93. doi: 10.1159/000261569.

12. Larsen MJ, Nyvad B. Enamel erosion by some soft drinks and orange juices relative to their $\mathrm{pH}$, buffering effect and contents of calcium phosphate. Caries Res. 1999;33(1):81-7. doi: 10.1159/000016499.

13. Edwards M, Creanor SL, Foye RH, Gilmour WH. Buffering capacities of soft drinks: the potential influence on dental erosion. J Oral Rehabil. 1999 Dec;26(12):923-27. doi: 10.1046/j.1365-2842.1999.00494.x.

14. Furtado JR, Freire VC, Messias DCF, Turssi CP. Aspectos físico-químicos relacionados ao potencial erosivo de bebidas ácidas. RFO UPF. 2010 Sep/Dec;15(3):325-30.
15. Ehlen LA, Marshall TA, Qian F, Wefel JS, Warren JJ. Acidic beverages increase the risk of in vitro tooth erosion. Nutr Res. 2008 May;28(5):299-303. doi: 10.1016/j.nutres.2008.03.001.

16. Lussi A, Jaeggi T. Chemical Factors. Monogr Oral Sci. 2006;20:77-87. doi: 10.1159/000093353.

17. Barbour ME, Rees GD. The role of erosion, abrasion and attrition in tooth wear. J Clin Dent. 2006;17(4):88-93.

18. Zero DT, Lussi A. Erosion-chemical and biological factors of importance to the dental practitioner. Int Dent $\mathrm{J}$. 2005;55(4 Suppl 1):285-90. doi: 10.1111/j.1875-595X.2005. tbooo66.x.

19. Jensdottir T, Bardow A, Holbrook P. Properties and modification of soft drinks in relation to their erosive potential in vitro. J Dent. 2005 Aug;33(7):569-75. doi: 10.1016/j. jdent.2004.12.002.

20. Meurman JH, Rytomaa I, Kari K, Laakso T, Murtomaa H. Salivary $\mathrm{pH}$ and glucose after consuming various beverages including sugar-containing drinks. Caries Res. 1987;21(4):353-9. doi: 10.1159/000261039. 